\title{
The ASEAN's responses to COVID-19: A policy sciences analysis
}

Riyanti Djalante1,*, Laely Nurhidayah2, Jonatan Lassa3, Hoang Van Minh4, Yodi Mahendradhata5, Nguyen Thi Ngoc Phuong4, Angelo Paolo L Trias6, Michelle Ann Miller7, Susanti Djalante,8,9, Muhammad Sabaruddin Sinapoy10

1. United Nations University - Institute for the Advanced Study of Sustainability (UNU-IAS), Japan, djalante@unu.edu,*Corresponding author

2.Indonesia Institute of Science (LIPI), Indonesia, lae_ly@yahoo.com

3. College of Indigenous Futures, Arts \& Society. Charles Darwin University, Australia, Jonatan.lassa@cdu.edu.au 4.Center for Population Health Sciences, Hanoi University of Public Health, Vietnam, hvm@huph.edu.vn ntnp@huph.edu.vn

5. Faculty of Medicine, Public Health and Nursing, Universitas Gadjah Mada, Indonesia, yodi_mahendradhata@yahoo.co.uk

6. S. Rajaratnam School of International Studies (RSIS), Nanyang Technological University, Singapore, isangelotrias@ntu.edu.sg

7. Asia Research Institute, National University of Singapore, Singapore, arimam@nus.edu.sg

8. Faculty of Engineering, Tokyo Metropolitan University, Japan, sdjalante@yahoo.com

9. Faculty of Engineering, Halu Oleo University, Indonesia

10. Faculty of Law, Halu Oleo University, Indonesia, sabaruddinsinapoy@yahoo.com

\begin{abstract}
The World Health Organisation (WHO) announced the new coronavirus disease (COVID-19) it as a pandemic on March 11th, 2020. The pandemic has brought havoc globally as more than 190 countries and territories are affected as of 30 April 2030. The crisis suggests that no country can deal with the pandemic alone. International cooperation including regional cooperation is essential for any country to survive. We are particularly interested in Association of South East Asian Nation (ASEAN) cooperation and performance under COVID-19 because it has been one of the regions where regional cooperation on health security has been functioning based on lessons from SARS 2003 and H1N1 2009. The "One Vision, One Identity, One Community” of ASEAN has merits under COVID-19 response but remains invisible. The method encompasses analysis of published materials issued by and accessible from the ASEAN website, complemented with analysis for media articles including social media, supported by published academic journal articles. All of the authors have expertise on ASEAN policies in the field of health, disasters, and regional policy and planning. Some authors have also worked from various international organisations working on issues related to the ASEAN region.
\end{abstract}

This paper aims to document and analyse how ASEAN member states respond to COVID-19. It asks how to cooperate under the One-ASEAN-One Response framework. This paper also compares the 10 member states' policy responses from January to April 2020. We utilise the framework of policy sciences to analyse the responses. We found that the early regional response was slow and lack of unity (January - February 2020). Extensive early measures taken by each member state are the key to the success to curb the spread of the virus. Although, during March and April 2020, ASEAN has reconvened and utilised its existing health regional mechanism to try to have a 
coherent response to the impacts. Strengthening future collaboration should be implemented by recognizing that there is a more coherent, multi sectoral, multi stakeholders and whole-of-ASEAN Community approach in ensuring ASEAN's timely and effective response to the pandemic.

Keyword: COVID-19, ASEAN, Pandemic, Policy, Disasters, Health, Regional cooperation, health system resilience

\section{Introduction: Existing health cooperation at ASEAN}

The new coronavirus disease (COVID-19) has brought havoc globally. The World Health Organisation (WHO) announced it as a pandemic on March 11th, 2020. It originates from the city of Wuhan in China, which then spread early to the neighbouring countries of South Korea, Japan and Iran. Due to its proximity and strong interconnections in tourism and trade, countries in the South East Asia region, countries part of the Association of Southeast Asian Nation (ASEAN) were affected early. The 10 ASEAN countries have reported at least 43,215 COVID-19 cases with 1,517 deaths in total as of 30 April 2020 (REF). Table 1 shows the impacts on April 30, 2020.

Table 1: Impacts of COVVID-19 in ASEAN (Source: https://www.csis.org/programs/southeast-asiaprogram/southeast-asia-covid-19-tracker-0)

\begin{tabular}{|l|l|l|l|l|l|l|}
\hline Country & Cases & $\begin{array}{l}\text { Cases last } \\
24 \text { hours }\end{array}$ & Deaths & Tests & Recovered & $\begin{array}{l}\text { Cases per } \\
\text { Million }\end{array}$ \\
\hline World & $3,212,519$ & 73,554 & 717,569 & N/A & 935,646 & 406 \\
\hline $\begin{array}{l}\text { Brunei } \\
\text { Darussalam }\end{array}$ & 138 & 0 & 1 & 13,428 & 124 & 322 \\
\hline Cambodia & 122 & 0 & 0 & 9,792 & 119 & 8 \\
\hline Indonesia & 9,771 & 260 & 784 & 67,784 & 1,391 & 37 \\
\hline Laos & 19 & 0 & 0 & 1,917 & 7 & 3 \\
\hline Malaysia & 5,945 & 94 & 100 & 154,212 & 4,087 & 191 \\
\hline Myanmar & 150 & 4 & 6 & 7,608 & 16 & 3 \\
\hline The Philippines & 8,212 & 254 & 558 & 98,941 & 1,023 & 78 \\
\hline Singapore & 15,641 & 690 & 14 & 143,919 & 1,128 & 2,787 \\
\hline Thailand & 2,947 & 9 & 54 & 58,107 & 2,665 & 42 \\
\hline Vietnam & 270 & 0 & 0 & 133,000 & 222 & 3 \\
\hline TOTAL ASEAN & 43215 & 1311 & 1517 & 688708 & 10782 & 3474 \\
\hline
\end{tabular}

COVID-19 response in ASEAN should interest scholars because ASEAN is one of the regional cooperation bodies in the world where regionalism serves as a platform for cooperation in the health security sector since 1980 (Association of Southeast Asean Nations (ASEAN) 2020a). Prior to COVID-19, ASEAN has been co-managing epidemics during SARS, H1N1 and MERS-CoV (Association of Southeast Asean Nations (ASEAN) 2020a). The ASEAN Community consists of three pillars, namely the ASEAN Political-Security Community, ASEAN Economic Community and ASEAN Socio-Cultural Community (ASCC) (Association of Southeast Asean Nations (ASEAN) 2020a). The ASEAN health cooperation is under ASCC pillar. "A Healthy, Caring and Sustainable ASEAN Community" is the vision of the ASEAN Post-2015 Health Development Agenda formulated in 2018 (Association of Southeast Asean Nations (ASEAN) 2018). We argue the pandemic scale events such as COVID-19 requires ASEAN to strengthen its work beyond national and often fragmented community model. A more coherent, multi 
sectoral, multi stakeholders and whole-of-ASEAN Community approach is necessary to ensure ASEAN's timely, tactical and effective response to the pandemic.

For COVID-19 response, under the ASCC umbrella, there are four most relevant existing mechanisms (Association of Southeast Asean Nations (ASEAN) 2020a). They are the ASEAN Health Ministers and ASEAN Plus Three Health Ministers and ASEAN Plus Three Senior Officials Meeting for Health Development (APT SOMHD), the ASEAN Emergency Operations Centre Network for public health emergencies (ASEAN EOC Network), and ASEAN BioDiaspora Virtual Centre for big data analytics and visualization (ABVC). Table 2 lists existing health security coordination and cooperation mechanisms that exist in ASEAN from SARS, H1N1 and recently COVID19.

Table 2: ASEAN existing health cooperation on Epidemic Preparedness Since SARS 2003 to COVID-19

\begin{tabular}{|c|c|}
\hline Timeline & Forms of cooperation \\
\hline $\begin{array}{l}2003-2009 \\
\text { SARS and } \\
\text { H1N1 }\end{array}$ & $\begin{array}{l}\text { ASEAN + } 3 \text { Emerging Infectious } \\
\text { Diseases (EID) Programme (2004-2008) } \\
\text { ASEAN Highly Pathogenic Avian Influenza (HPAI) Task Force } \\
\text { ASEAN Cooperation on Animal Health } \\
\text { ASEAN Work Programme on HIV/ AIDS III (2006-2010) } \\
\text { ASEAN-Japan Project for Stockpile of Antivirals and PPE against Potential Pandemic Influenza } \\
\text { (2006-2013) } \\
\text { Regional Framework for Control and Eradication of HPAI (2006-2008) } \\
\text { ASEAN Assessment of National Multi-Sectoral Pandemic Preparedness and Response (2007- } \\
\text { 2010) } \\
\text { Regional Strategy for Progressive Eradication of HPAI (2008-2010) } \\
\text { ASEAN + 3 Partnership Laboratories (APL) } \\
\text { MOU between ASEAN Secretariat and WHO }\end{array}$ \\
\hline $\begin{array}{l}2010-2019 \\
\text { Broader } \\
\text { health risks }\end{array}$ & $\begin{array}{l}\text { One ASEAN One Response Framework in ASEAN Agreement on Disaster Management and } \\
\text { Emergency Response (AADMER) } \\
\text { Disaster Safety of Health Facilities in the AADMER Work Programme (2010-2015) } \\
\text { ASEAN + } 3 \text { Field Epidemiology Training Network (FETN) } \\
\text { ASEAN Risk Communication Resource Centre }\end{array}$ \\
\hline $\begin{array}{l}2020 \\
\text { COVID-19 }\end{array}$ & $\begin{array}{l}\text { ASEAN Plus Three Senior Officials Meeting for Health Development (APT SOMHD) } \\
\text { Mechanism Responding to COVID-19 } \\
\text { ASEAN Health Ministers and ASEAN Plus Three Health Ministers in Enhancing } \\
\text { Cooperation on COVID-19 } \\
\text { ASEAN Emergency Operations Centre (EOC) Network for public health emergencies } \\
\text { ASEAN BioDiaspora Virtual Centre (ABVC) for Big Data Analytics and Visualisation } \\
\text { ASEAN Coordinating Council Working Group (ACCWG) on Public Health Emergencies } \\
\text { ASEAN Plus Three Field Epidemiology Training Network (ASEAN+3 FETN) } \\
\text { ASEAN Risk Assessment and Risk Communication Centre (ARARC) } \\
\text { Public health laboratories network under the ASEAN Health Cluster } 2 \text { on Responding to All } \\
\text { Hazards and Emerging Threats } \\
\text { Regional Public Health Laboratories Network (RPHL) through the Global Health Security Agenda } \\
\text { platform }\end{array}$ \\
\hline
\end{tabular}


This paper aims to document and analyse how ASEAN member states responses to COVID-19. We argue that existing regional health collaboration since 2003 and coupled with the One-ASEAN-One Response framework should have provided a strong foundation for the region to deal with the impacts. We find that the early (January February 2020) regional response was slow and lack of coherence. Extensive early measures taken by each member state are the key to the success to curb the spread of the virus. Although, between March and April 2020, ASEAN reconvened and utilised its existing health regional mechanism to try to have a coherent response to the impacts. The specific objectives are:

1. To review the impacts of COVID-19 at the ASEAN level and analyse recent ASEAN regional responses specifically to COVID-19,

2. To report country's responses to COVID-19 from February to April 2020,

3. To compare these responses utilising policy science viewpoints and identify lessons learnt on how to strengthen regional responses and in the long term, the health systems resilience of ASEAN and its member states.

The paper is developed primarily through analysis of published materials issued by and accessible from the ASEAN website, complemented with analysis for media articles including social media. Published academic journal articles are used in the analysis. All of the authors have expertise on ASEAN policies in the field of health, disasters, and regional policy and planning. Some authors have worked for international organisations working on issues related to the ASEAN region. The paper is organised as follows. Section 1 examines the aim, objectives and rationale for the paper. The section further reviews existing and relevant regional mechanisms. Section 2 documents the impacts at the regional scale and key health-responses responses coordinated by the ASEAN. Section 3 compares health-related and broader responses amongst the 10 countries. In Section 4, using the policy science viewpoints proposed by Weible et al, we examined and compared these responses (Weible et al. 2020). We conclude with a statement on broader ASEAN health systems' resilience in Section 5.

\section{Impacts on ASEAN and ASEAN health sector efforts to COVID-19}

\subsection{Impacts on ASEAN}

The ASEAN countries, with a combined population of 649 million and GDP of US $\$ 2.8$ trillion, have been badly hit by COVID-19. Key sectors that have been affected by lockdown and other measures include travel, tourism, retail, supply chain, manufacturing sectors and other services (Assian Development Bank 2020). Employment and livelihood people of the region are also significantly affected. In ASEAN, the uncertainties brought about by the pandemic also triggered a swift outflow of capital, causing a dive in the markets and a rapid depreciation of the exchange rates across the region. Despite the disruption on the economic sector, the ADB has forecast the economic growth of Southeast Asia will be around 1\% (Assian Development Bank 2020). The confirmed cases by 29 April 2020 of 43,215, with Singapore, Philippines and Indonesia suffer the most, Singapore has 15,641, Indonesia 9,771, Philippines 8,212 cases, Malaysia 5,945, Thailand 2,947, Vietnam 270, Brunei 138, Cambodia 122, Myanmar 150, and Laos 19 (Association of Southeast Asean Nations (ASEAN) 2020c). Figure 1 shows the Epi curve of confirmed cases by 30 April 2020 (Association of Southeast Asean Nations (ASEAN) 2020c). 
Figure 1: COVID-19 epi curve confirmed cases (Source: (Association of Southeast Asean Nations (ASEAN) 2020c)

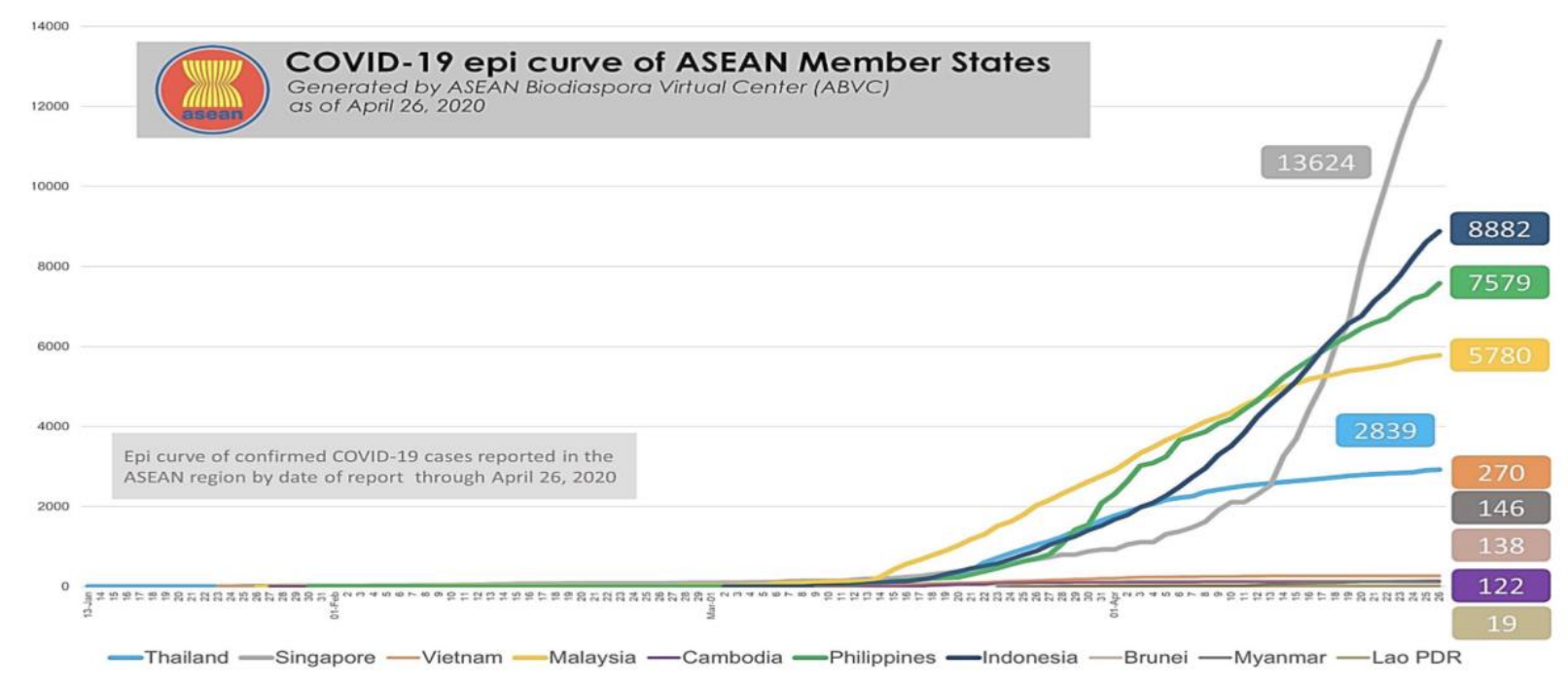

\subsection{ASEAN health sector efforts to COVID-19}

The impacts have harmed the life of all citizen in the region and their socio economic and threatening sustainability and social security (Gong 2020). ASEAN as a regional body in southeast Asia has an important role to coordinate cooperation between member states to contain the spread of the virus in the region as it is a transboundary problem (Gianna Gayle Herrera Amul and Tikki Pang 2018). Figure 2 shows the webpage of the ASEAN coordinated response to COVID-19.

Figure 2: Website of ASEAN coordinated response to COVID-19 (ASEAN, 2020)
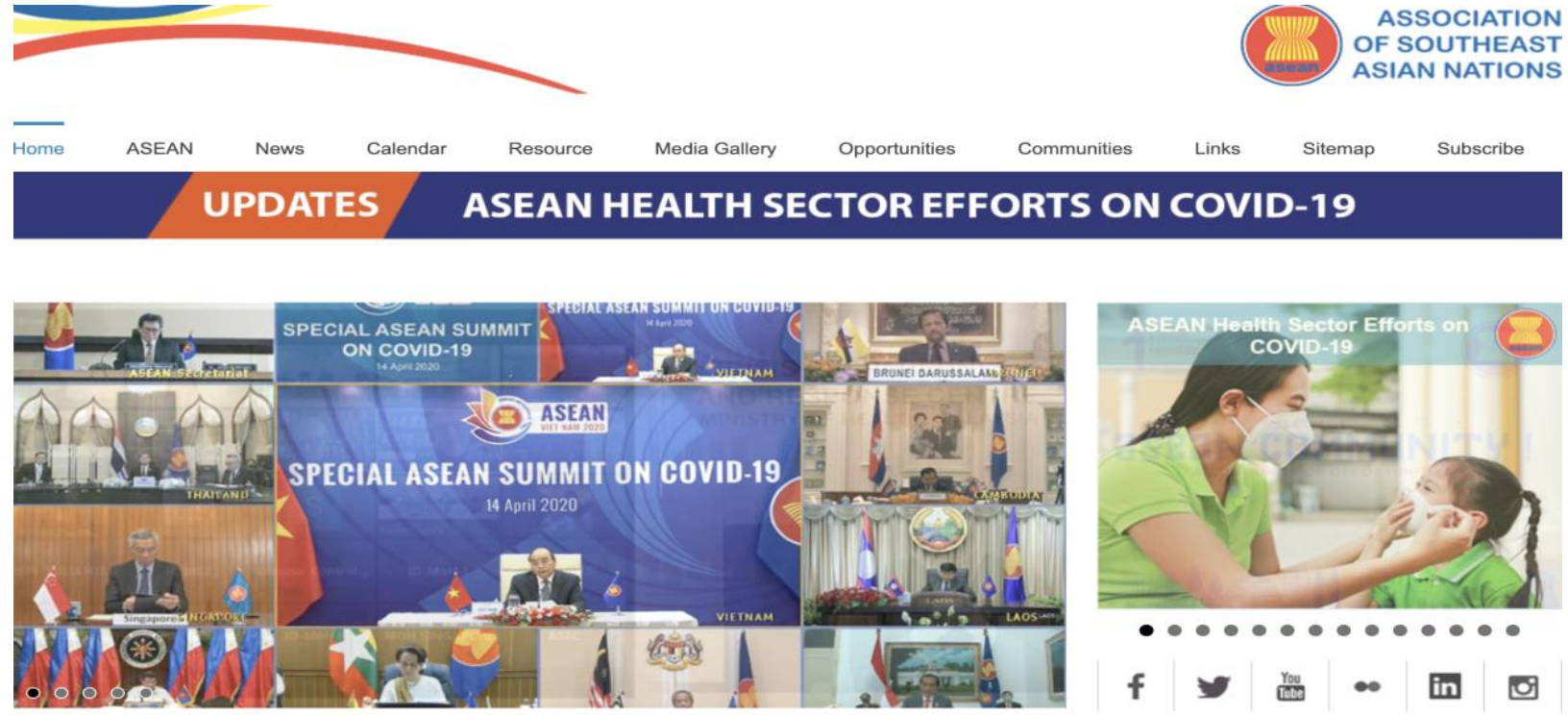

While the early effort of ASEAN has been limited to communication exchange and information sharing among member states on current situation and response updates. A further commitment of concerted efforts and collective 
action is needed to prevent and eliminate the risk of pandemic in the region particularly to assist the Member States that suffer the most of social and economic from the impact of pandemic. Table 3 summarises the timeline of key responses.

Table 3: Key timeline of ASEAN responses to COVID-19 (Source: Authors, compiled from ASEAN, 2020)

\begin{tabular}{|c|c|c|}
\hline Month & Date & Responses \\
\hline $\begin{array}{l}31 \mathrm{Dec} \\
2019\end{array}$ & & First COVID-19 case in Wuhan, China \\
\hline \multirow[t]{2}{*}{$\begin{array}{l}\text { February } \\
2020\end{array}$} & 19 & $\begin{array}{l}\text { Joint statement of ASEAN Defence Ministers on Defence Cooperation against Disease } \\
\text { Outbreak }\end{array}$ \\
\hline & 20 & The ASEAN Coordinating Council (ACC) Special Meeting \\
\hline \multirow{3}{*}{$\begin{array}{l}\text { March } \\
2020\end{array}$} & 9 & ASEAN health sector sustains cooperation in responding to COVID-19 \\
\hline & 10 & $\begin{array}{l}\text { Strengthening ASEAN'S Economic Resilience in Response to The Outbreak of The } \\
\text { Coronavirus Disease }\end{array}$ \\
\hline & 13 & $\begin{array}{l}\text { ASEAN senior health officials enhance regional collective actions against COVID-19 } \\
\text { pandemic }\end{array}$ \\
\hline \multirow[t]{11}{*}{ April 2020} & 7 & $\begin{array}{l}\text { Joint Statement Special Video Conference of ASEAN Plus Three Health Ministers in } \\
\text { Enhancing Cooperation on Coronavirus Disease } 2019 \text { (COVID-19) Response }\end{array}$ \\
\hline & 9 & $\begin{array}{l}\text { Joint Statement Special Video Conference of The ASEAN Health Ministers in Enhancing } \\
\text { Cooperation on COVID-19 Response }\end{array}$ \\
\hline & 10 & $\begin{array}{l}\text { ASEAN Ministers Endorse New COVID-19 Response Fund } \\
\text { Policy Brief on the Economic Impact of COVID-19 Outbreak on ASEAN released }\end{array}$ \\
\hline & 13 & $\begin{array}{l}\text { Joint Statement Special Video Conference of ASEAN Plus Three Health Ministers in } \\
\text { Enhancing Cooperation on Coronavirus Disease } 2019 \text { Response }\end{array}$ \\
\hline & 14 & Declaration of the special ASEAN summit on Coronavirus Disease 2019 \\
\hline & & A series of ASEAN and other countries activities \\
\hline & 17 & ASEAN, Italian health experts exchange experiences in combating COVID-19 \\
\hline & 21 & China donates medical supplies to ASEAN Secretariat for COVID-19 prevention \\
\hline & 22 & $\begin{array}{l}\text { ASEAN - Japan Economic Ministers' Joint Statement on Initiatives on Economic } \\
\text { Resilience in Response to the Corona Virus Disease Outbreak }\end{array}$ \\
\hline & 23 & $\begin{array}{l}\text { Co-Chairs' Statement of the Special ASEAN-United States Foreign Ministers' Meeting on } \\
\text { Coronavirus Disease } 2019\end{array}$ \\
\hline & 24 & ASEAN, China reaffirm commitment to forge closer cooperation \\
\hline
\end{tabular}


ASEAN Vision 2025 on Disaster Management highlights the importance of communication exchange between stakeholders involved. Since the official outbreak announcement in China, ASEAN Emergency Operations Centre Network for public health emergencies (ASEAN EOC Network), led by Malaysia, has taken initiative in sharing daily situational updates on the diseases. ASEAN EOC Network for public led by the Ministry of Health of Malaysia provides a platform among ASEAN member states officials working at respective crisis centres and/or disease prevention and control to share information in a timely manner through various mechanisms of communication. They set up a WhatsApp mobile application for that purpose. EOC network produces compilation on National/local Hotline/Call Centre in ASEAN Member State which then shares to the public on social media. The ASEAN BioDioaspora Regional Virtual Centre (ABVC) for big data analytics and visualisation complemented with providing a report on the national risk assessments, readiness and response planning efforts. ASEAN publishes Risk assessment report for international dissemination of COVID-19 to the ASEAN region on 10 April 2020 by ASEAN Biodiaspora Virtual Center (ABVC) to provide highlights responses and the situation overview cases and deaths in ASEAN countries.

Communication exchange was conducted through online meetings such as ASEAN health sector effort in the prevention, detection and response to COVID-19. ASEAN Health Minister (AHHM) chaired by Indonesia health Minister on 7 April 2020 convened video conference to intensify regional cooperation with various stakeholders and to step up measures to control the spread and mitigate the pandemic. According to this meeting the agreed on (1) Further strengthening regional cooperation on risk communication to avert misinformation and fake news; (2) Continue sharing information, research and studies in an open, real-time and transparent, (3) Coordinating crossborder health responses; scaling-up the use of digital technology and artificial intelligence for efficient information exchanges, (4) Strengthening and institutionalising preparedness, surveillance, prevention, detection and response mechanisms of ASEAN with other partners.

Further action has been agreed by the leaders which issued a declaration of special summit ASEAN which proposed to establish the COVID-19 ASEAN Response Fund to boost emergency stockpiles for future outbreaks (Association of Southeast Asean Nations (ASEAN) 2020c). ASEAN has invited ASEAN Plus 3 (Japan, South Korea and China) to contribute for this fund. The finance and resource mobilisation are crucial to assist the member states in procuring medical supplies and equipment as currently lacking in some regions. The Strengthening collaboration has been called by the Declaration of the special ASEAN summit on Coronavirus Disease 2019 (14 April 2020). The following 7 measures that have been agreed by the declaration include: (1) further strengthen public health cooperation measures to contain the pandemic and protect the people. (2) Making arrangements to preserve supply chain connectivity, (3) Further work based on a multi-stakeholder, multi-sectoral, and comprehensive approach by ASEAN to effectively respond to COVID-19 and future public health emergencies, (4) Take collective action and coordinate policies in mitigating the economic and social impact from the pandemic, safeguarding the people's wellbeing and maintaining socio-economic stability, (5) Enhance effective and transparent public communication involving multiple forms of media including timely updates of relevant government policies, public health and safety information, clarifications on misinformation, and efforts to reduce stigmatisation and discrimination, (6) Prioritise the well-being of our peoples in ASEAN's collective fight against COVID-19, and provide appropriate 
assistance and support to the nationals of ASEAN Member States affected by the pandemic in each other's country or in third countries, (7) Support reallocating existing available funds and encourage technical and financial support from ASEAN's partners to facilitate cooperation, including the proposed establishment of the COVID-19 ASEAN Response Fund.

\section{Country specific responses}

This section reports government responses taken by the individual countries. It has been proposed that countrybased mitigation is extremely important to fight COVID-19 as country is the first line of defence against it (Anderson et al. 2020).

\subsection{Brunei Darussalam}

Brunei is a tiny country with the population around 436,647 has emerged as good example of a country that provides care, concern, and preparedness not only to its citizens but also to foreign and tourist (Asif Ullah Khan 18 April 2020).The handling of the pandemic by the Sultan Bolkiah has been argued as transparent and robust. The first case was declared on 9 March 2020. Brunei has successfully contained the virus in small number cases compared to the other ASEAN countries. It recorded 136 cases and on 6 April no new cases emerged (Nile Bowie April 2, 2020). Brunei has taken necessary steps to contain the virus, including early massive testing since January 2020. travel bans for citizens to go abroad on March 15 (Nile Bowie April 2, 2020). All Bruneians returning to the country undergo mandatory isolation at quarantine facilities. Brunei has entirely implemented lockdown and closed its access from sea, air on March 24 (Nile Bowie April 2, 2020).Restrictions of public gathering, work from home, mosque and other worship places has been closed. The government also took measures to ensure the welfare of its citizens. The Ministry has issued a directive to all employers to pay salaries during the quarantine to its employees. On April 1, it introduced economic stimulus for micro, small and medium enterprises for BND250 million (USD 175 million). The success of Brunei in containing the virus is early action and implemented precautionary measures and deploy and mobilize all funding and resources to ease the impact of the pandemic.

\subsection{Cambodia}

The population of Cambodia is around 16 million people. The first confirmed cases of coronavirus in Cambodia has been reported on 27 January 2020 (The Star 07 Mar 2020). The country has confirmed 122 cases of COVID-19 so far and no deaths have been reported (Worldometers 2020). No new cases were reported in Cambodia for 12 consecutive days. Despite this situation Cambodia Prime Minister urged people to remain vigilant as there is no medicine to cure this infectious disease (Star MY 25 Apr 2020). Cambodia has lowest confirmed cases compared to other ASEAN countries despite criticism of lack testing (Rebecca Ratcliffe 10 Apr 2020). Several measures that have been adopted by The Royal government of Cambodia include imposed quarantine, cancel the celebrations of the Khmer New Year, issued economic stimulus (KPMG 15 April, 2020). In addition, the government also passed state of emergency law on 10 April 2020 granting the country's autocratic leader, Hun Sen, vast new powers allowing the government to carry out unlimited surveillance of telecommunications and to control the press and social media (Rebecca Ratcliffe 10 Apr 2020). Human rights experts argued that this law expected to weaken democracy right in the country. 


\subsection{Indonesia}

Indonesia is the most populous country among ASEAN members with 272 million people. The risk in suffering most due to the coronavirus pandemic is amounting as the quality of health infrastructure has been inadequate. This is shown by the number cases continues to rise and second in the region after Singapore and the mortality rate of 8.9 to $9 \%$ is one of the highest in the Southeast Asia and the world (Anne Barker and Hellena Souisa 23 MarMarch 2020). Confirmed first cases of coronavirus in Indonesia was announced by President Joko Widodo on 2 March 2020. It first rejected findings from a study from Harvard University about the possibility COVID-19 infections. Detailed analysis on COVID-19 response in Indonesia have been recently published by Djalante et al (Djalante et al. 2020). Several key measures have been issued to respond to the coronavirus cases in Indonesia include: The establishment of Task force for the acceleration of COVID-19 on 13 March 2020. Large scale social restriction (PSBB) for accelerating COVID-19 eradication on 30 March 2020. On 24 April 2020 Indonesia issued domestic travel restriction during Ramadhan period until 3 of June. There is now suspension of travels between cities by air, land and water. In addition, the government has decided to implement a travel ban for foreign visitors to Indonesia including transit since 2 April 2020 through the Ministry of Law and Human Rights No 11/2020 on temporary travel bans for foreigners who enter Indonesia territory. On 31 March 2020, 405 trillion Rupiah (USD 26.5 billion) Stimulus package was announced by government regulation in lieu of law (Регрри) No 1/2020 to legitimize much more state spending and financial relief (International Science Council 2020).

\subsection{Lao People Democratic Republic (Lao PDR)}

Lao People's Democratic Republic with a population 7,254,007 people is the last country in ASEAN infected by coronavirus. The first two cases of coronavirus have confirmed on 24 March 2020. The number of confirmed cases in Laos only 19 and it is reported there is no new cases for 9 consecutive days in April 21 (The Star 17 Apr 2020). In responding to corona virus several measures have been taken include: established National Taskforce Committee for COVID-19 Prevention and Control-a special taskforce established on February 3, 2020 (Santaniello March 30, 2020). On March 29, 2020, the Prime Minister of Laos issued Order No. 06/PM on the Reinforcement of Measures for the Containment, Prevention, and Full Response to the COVID-19 Pandemic. These Order have issued following measure such as closing some provincial borders, prohibition of gathering more than 10 people, price control, residential lockdown, and work from home for government officials. These measures have been implemented from March 30 to April 19, 2020 (Santaniello March 30, 2020). LAO PDR government he Lao PDR government has already allocated LAK10 billion for implementing measures to prevent and control the spread of COVID-19 in the country and other key fiscal, monetary and macroeconomic measures (VDB Loi April 3, 2020).

\subsection{Malaysia}

Malaysia with a population of around 31 million people has joined the list of countries with coronavirus when the first case was confirmed on 25 January 2020 (Duddu 1 April 2020). Malaysia can maintain the confirmed cases low before sudden outbreak due to mass religious gathering attended by 16,000 people at the end of February 2020 (Anne Barker 19 March 2020). Malaysia's nationwide response and collaboration can be a model for other countries to help flatten the curve of the COVID-19 pandemic (The Star 24 Mar 2020). The key measures include on 13 
March 2020, the government has banned all gatherings, including international meetings, sporting events, social and religious assemblies until 30th of April 2020. On 18 March 2020, the government decided to implement the Movement Control Order until March 31 to address the outbreak under the Prevention and Control of Infectious Diseases Act 1988 and the Police Act 1967. Malaysian government launched a series of economic stimulus measures to lessen the impacts to the sectors and communities. The Malaysian government announced a stimulus package worth RM20 billion (USD 4.56 billion) to enable the tourism and other industries in the country to deal with the impact of the coronavirus pandemic. A second stimulus package worth RM250 billion (USD58 billion) was announced, out of which RM25bn (USD6 billion) will be provided to help families and business owners affected by the outbreak.

\subsection{Myanmar}

Myanmar's population currently stood around 54,336,457. Myanmar's first confirmed case was on 24 March 2020 (Bangkok Post 24 Mar 2020). Despite the confirmed cases being relatively small compared to other ASEAN countries, there is a fear of a major outbreak due to slow widespread testing in the country (Andrew Nachemson 1 Apr 2020). The United Nations has announced a plan to donate 50,000 testing kits to Myanmar, supplementing previous donations of 3.000 from Singapore and 5,000 from South Korea. The country is vulnerable, the public health system in Myanmar is woefully unsuited in response for a pandemic scale. In addition, there is no safety net in Myanmar which causes the poor to be the most vulnerable groups in times of health and economic crisis as an impact of pandemic (Ei Ei Toe Lwin 18 Apr 2020). The lockdown will hurt the livelihood and food security of the country. Yangon imposed lockdown measures in seven townships from 6 PM on 18 April 2020 through Ministry of Health and Sport Order No. 38/2020 the Prevention and Control of Communicable Diseases Law. To ease the impact of the pandemic the government announced an initial stimulus package including 100 billion Kyats (USD70 million). The fund will be used to assist garment and manufacturing, hotel and tourism business as well as small and medium size enterprises owned by local people (Nan Lwin 19 March 2020).

\subsection{The Philippines}

The Philippines is the second most populous country in ASEAN with 106 million. The first imported case was reported in January 2020 and the first local transmission was confirmed in early March (WHO, 2020a). As of 22 April, 91.5 percent of the 6,710 confirmed cases and 87 percent of the total reported deaths come from Luzon - the largest and most populous island in the country (WHO, 2020b). The official COVID-19 response of the Philippines has three core elements: (i) granting 'special temporary power' to the President by Congress, (ii) imposing a lockdown on the entire island of Luzon, (iii) employing the military and police to enforce the President's orders and lockdown measures (CSIS, 2020). The Inter-Agency Task Force on Emerging Infectious Diseases responsible for containing the spread of the coronavirus works alongside a National Task Force in charge of commanding operations (Office of the President, 2014; Sadongdong, 2020). The National Action Plan and nationwide tracker are the main tools used to support decentralization and decision making (Department of Health, 2020). Signing into law Republic Act No.11469 or 'Bayanihan to Heal as One Act' initiated an economic stimulus to provide relief to affected populations (Congress of the Philippines March 25, 2020). This includes a $\$ 3.9$ billion social protection 
program that offers aid to poor families, earners in the informal sector, health workers who contracted COVID-19, and families of health workers who died from the disease (Congress of the Philippines March 25, 2020). A \$610 million 'Bayanihan Grant to Cities and Municipalities' to assist local government units in responding to the health crisis was approved (Department of Budget and Management 2020). Finally, a \$1 billion wage subsidy package was allotted to support social security and workers of small businesses (Finance 14 Apr 2020). The country was also placed under a 'state of calamity' so government can access disaster financing like Calamity and 'Quick Response Funds' (Paunan, 2020).

\subsection{Singapore}

Singapore confirmed its first imported case from Wuhan, China, on 23rd January 2020 (Zhaki Abdullah and Hidayah Salamat 23 Jan 2020). Singapore was hailed globally as a model for emulation and replication by governments, epidemiologists and the mass media for "flattening the curve" through its extensive testing, contact tracing and strict quarantining of infected cases. Even on 24th March 2020, when Singapore took the unprecedented step of closing its international borders to stem the spike in imported cases (Grace Ho 24 March 2020) - including from many ASEAN countries where limited testing masked the spread of infections across the region (Athira Nortajuddin 31 March 2020). Local transmissions remained relatively low and were linked mainly to known clusters identified through contact tracing. By early April 2020, however, a major outbreak of infections among Singapore's migrant workers saw the island-state with a population of 5.7 million people overtake all other ASEAN countries in recording the highest number of COVID-19 cases (Department of Statistics Singapore 2020). To contain the outbreak, Singapore's Prime Minister Lee Hsien Loong announced nation-wide circuit breaker measures to enforce social distancing from 7th April until 4th May, which were subsequently extended until 1st June 2020 (Linette Lai 22 Apr 2020). The government also intensified testing in 43 dormitories that housed 200,000 South and Southeast Asian migrants employed primarily in the construction sector. Media coverage of the migrant dormitory outbreak focused on the relative vulnerability of these workers due to their close proximity in working, travelling and living conditions, impeding their capacity to practice safe social distancing (Hillary Leung 20 Apr 2020; Jessie Yeung April 25, 2020).

\subsection{Thailand}

Thailand with the population about 69,766,356, has reported the first country in ASEAN and outside china infected by COVID-19 on 13 January 2020 (Praveen Duddu 31 Mar 2020). Thai government has announced partial lock down to contain the spread of the virus. Covid-19 situation in Thailand is improving as the number of new cases falls, with no new imported cases due a near total ban on incoming flights since early April (Praveen Duddu 31 Mar 2020). There is a criticism of lack of testing and suspicious low number cases reported (Greeley Pulitzer 19 Apr 2020). Thailand confirmed cases approximately 2000. The measures to contain the virus include: The country was placed under a state of emergency on 26 March until 30 April (Praveen Duddu 31 Mar 2020). The government has announced the cancellation of the Thai New Year celebrations called Songkran. The island of Phuket has been placed under lock-down from 30 March to contain the spread of coronavirus (Praveen Duddu 31 Mar 2020). Thailand's prime minister announced a nationwide 10 p.m. to 4 a.m. curfew starting April 22020 to combat further 
the spread of corona virus (Associated press April 02, 2020). As economic stimulus, the first package, valued at 100 billion baht (3.2 billion), also focused on supporting businesses in the form of low-interest loans, deductions in withholding tax, and VAT refunds. on March 24, 2020, the Thai government issued its second stimulus worth 117 billion baht (US\$3.56 billion) (Ayman Falak Medina April 16, 2020). Thailand plan to new borrowing of 1 trillion baht (US \$30,6 billion) for its latest stimulus package for economy impact of COVID-19 (Suttinee Yuvejwattana 7 Apr 2020).

\subsection{Vietnam}

Although Vietnam shares the long and bustling border with China, the pandemic is still under the government's control by applying various rapid responses. With the total population of 97.3 million people, the first case was confirmed on January 23rd, 2020 (Vietnam Ministry of Health 2020). After three months since it was detected, the Vietnam government confirmed a total of 270 cases. Of which, 225 cases had recovered, and no death was recorded as of April 26 (Vietnam Government news 26 Apr 2020). The Vietnamese government demonstrated their prompt and aggressive response in the fight with such unprecedented diseases (Minh Duc 2020). In early February, Vietnam was the first nation after China to put a large residential area into the isolation zone to curb the negative impact of the COVID-19 pandemic. By isolating infected people and tracking down their contacts, the communities or villages, where were at risk of this pandemic since having close relation with the infected person, could be completely sealed off (Vietnam Government news 03 Apr 2020). Together with stopping issuing visas for foreigners from infected nations, all international flights coming to or departing from the pandemic areas were suspended as soon as the first case was confirmed. Vietnam temporarily cleared from the pandemic at the end of April 2020. Vietnam required all Vietnamese and international visitors who returned from abroad to quarantine at centralized facilities for 14 days, followed by the implementation of nationwide quarantine on April 1st, 2020 (Vietnam Government 2020). To further prevent the spread of this pandemic, border crossings between Vietnam and Cambodia and Laos were temporarily.

All of the above discussion is summarised in Table 4 and 5 below.

Table 4: Summary of country responses to COVID-19 (Source: Authors, compiled from different sources)

\begin{tabular}{|c|c|c|c|c|c|c|c|}
\hline \multirow{2}{*}{$\begin{array}{l}\text { Countr } \\
y\end{array}$} & \multirow[b]{2}{*}{$\begin{array}{l}\text { Key } \\
\text { regulatio } \\
\text { ns / New } \\
\text { structur } \\
\text { e formed }\end{array}$} & \multirow{2}{*}{$\begin{array}{l}\text { Overall } \\
\text { status (As } \\
\text { of April } \\
\text { 2020) }\end{array}$} & \multicolumn{5}{|c|}{ National responses to the COVID-19 pandemic } \\
\hline & & & $\begin{array}{l}\text { Closing } \\
\text { of } \\
\text { border } \\
\text { crossing } \\
\mathrm{S}\end{array}$ & $\begin{array}{l}\text { Travel } \\
\text { restrictio } \\
\text { ns or } \\
\text { entry } \\
\text { prohibitio } \\
\text { ns } \\
\end{array}$ & $\begin{array}{l}\text { Closing of } \\
\text { non-essential } \\
\text { businesses, } \\
\text { schools, and } \\
\text { other public } \\
\text { places }\end{array}$ & $\begin{array}{l}\text { Quarantine } \\
\text { or lockdown }\end{array}$ & $\begin{array}{l}\text { Provision } \\
\text { of } \\
\text { Economic } \\
\text { stimulus }\end{array}$ \\
\hline $\begin{array}{l}1 . \\
\text { Brunei }\end{array}$ & $\begin{array}{l}\text { Ministry } \\
\text { of Health } \\
\text { as the } \\
\text { coordinat } \\
\text { ing } \\
\text { agency }\end{array}$ & $\begin{array}{l}\text { Almost all } \\
\text { of the } \\
\text { confirmed } \\
\text { cases were } \\
\text { found to be } \\
\text { linked with } \\
\text { a wide- }\end{array}$ & $\begin{array}{l}\text { Closed } \\
\text { by } \\
\text { Malaysia } \\
\text {. }\end{array}$ & $\begin{array}{l}\text { All travels } \\
\text { in and out } \\
\text { of Brunei } \\
\text { are } \\
\text { banned } \\
\text { from } \\
\text { March } 24\end{array}$ & $\begin{array}{l}\text { Prohibit mass } \\
\text { gatherings } \\
\text { from April } 6 . \\
\text { Online classes } \\
\text { are still open } \\
\text { until mid of } \\
\text { May. Malls are }\end{array}$ & $\begin{array}{l}\text { A two-week } \\
\text { quarantine is } \\
\text { applied for all } \\
\text { citizens and } \\
\text { visitors } \\
\text { beginning of } \\
\text { April } 6 .\end{array}$ & $\begin{array}{l}\text { Special } \\
\text { aiding for } \\
\text { healthcare } \\
\text { workers } \\
\text { and } \\
\text { individuals } \\
\text { affected by }\end{array}$ \\
\hline
\end{tabular}




\begin{tabular}{|c|c|c|c|c|c|c|c|c|c|}
\hline & & $\begin{array}{l}\text { reach } \\
\text { religious } \\
\text { event in } \\
\text { Malaysia at } \\
\text { the end of } \\
\text { February. }\end{array}$ & & $\begin{array}{l}\text { and March } \\
16, \\
\text { respectivel } \\
\text { y. }\end{array}$ & \multicolumn{4}{|c|}{$\begin{array}{l}\text { recommended } \\
\text { to limit their } \\
\text { customer } \\
\text { number per } \\
\text { serve and } \\
\text { provide } \\
\text { takeout orders } \\
\text { for restaurants. }\end{array}$} & $\begin{array}{l}\text { the } \\
\text { pandemic. } \\
\text { BND250 } \\
\text { million } \\
\text { (USD 175 } \\
\text { million) }\end{array}$ \\
\hline $\begin{array}{l}\text { 2.Camb } \\
\text { odia }\end{array}$ & $\begin{array}{l}\text { State of } \\
\text { Emergen } \\
\text { cy Law } \\
10 \text { April } \\
2020\end{array}$ & $\begin{array}{l}\text { Underestim } \\
\text { ate the risk } \\
\text { and initially } \\
\text { refused to } \\
\text { apply strict } \\
\text { action } \\
\text { because of } \\
\text { maintaining } \\
\text { the close } \\
\text { relationship } \\
\text { with China }\end{array}$ & $\begin{array}{l}\text { Closed } \\
\text { by } \\
\text { neighbou } \\
\text { ring } \\
\text { countries } \\
\text {. }\end{array}$ & $\begin{array}{l}\text { On March } \\
17, \text { ban on } \\
\text { travellers } \\
\text { come from } \\
\text { several } \\
\text { high-risk } \\
\text { nations. } \\
\text { March 30, } \\
\text { temporaril } \\
\text { y } \\
\text { suspendin } \\
\text { g all visas } \\
\text { types. } \\
\text { April 10, } \\
\text { travel } \\
\text { within the } \\
\text { nation } \\
\text { including } \\
\text { district } \\
\text { and } \\
\text { provincial } \\
\text { borders is } \\
\text { prohibited }\end{array}$ & $\begin{array}{l}\text { April 1, } \\
\text { closing } \\
\text { casinos } \\
\text { and } \\
\text { schools. } \\
\text { March } \\
31, \\
\text { "sharing } \\
\text { informati } \\
\text { on" is } \\
\text { prohibited }\end{array}$ & \multicolumn{2}{|c|}{$\begin{array}{l}\text { On April } \\
8, \\
\text { imposed } \\
\text { a } \\
\text { quarantin } \\
\text { e on all } \\
\text { visitors } \\
\text { entering } \\
\text { Cambodi } \\
\text { a }\end{array}$} & \multicolumn{2}{|c|}{$\begin{array}{l}\text { Fiscal resources for } \\
\text { the health sector and } \\
\text { only "legally } \\
\text { registered and } \\
\text { formally verified" } \\
\text { businesses, meaning } \\
\text { that } 95 \% \text { will be } \\
\text { excluded. }\end{array}$} \\
\hline $\begin{array}{l}\text { 3.Indon } \\
\text { esia }\end{array}$ & $\begin{array}{l}\text { Health } \\
\text { Emergen } \\
\text { cy Law } \\
31 \\
\text { March } \\
2020 \\
\\
\text { Special } \\
\text { Task } \\
\text { Force on } \\
\text { COVID- } \\
19\end{array}$ & $\begin{array}{l}\text { A rapid } \\
\text { increase in } \\
\text { cases are } \\
\text { observed } \\
\text { together } \\
\text { with the } \\
\text { highest } \\
\text { mortality } \\
\text { rate in } \\
\text { ASEAN. }\end{array}$ & $\begin{array}{l}\text { Land } \\
\text { borders } \\
\text { with } \\
\text { Timor- } \\
\text { Leste } \\
\text { and in } \\
\text { Papua } \\
\text { province } \\
\text { are } \\
\text { closed. }\end{array}$ & $\begin{array}{l}\text { All } \\
\text { visitors } \\
\text { are } \\
\text { prohibited } \\
\text { starting } \\
\text { April } 2\end{array}$ & \multicolumn{2}{|c|}{$\begin{array}{l}\text { Large Scale } \\
\text { Social } \\
\text { Restriction is } \\
\text { implemented } \\
\text { with domestic } \\
\text { intercity air } \\
\text { land and sea is } \\
\text { suspended to } \\
\text { prevent mass } \\
\text { people } \\
\text { movement as } \\
\text { Ramadhan } \\
\text { approaches }\end{array}$} & \multicolumn{2}{|c|}{ Not yet } & $\begin{array}{l}\text { Indonesia's } \\
\text { third } \\
\text { stimulus } \\
\text { package } \\
\text { was } \\
\text { introduced } \\
\text { on March } \\
31 . \\
405 \text { trillion } \\
\text { Rupiah } \\
\text { (USD 26.5 } \\
\text { billion) }\end{array}$ \\
\hline 4.Laos & $\begin{array}{l}\text { Prime } \\
\text { Minister } \\
\text { Order } \\
29 \\
\text { March } \\
2020\end{array}$ & $\begin{array}{l}\text { The last } \\
\text { country in } \\
\text { ASEAN to } \\
\text { report } \\
\text { infections } \\
\text { together } \\
\text { with the } \\
\text { non-existent } \\
\text { health care } \\
\text { system and } \\
\text { weak } \\
\text { governance. }\end{array}$ & $\begin{array}{l}\text { Closed } \\
\text { the road } \\
\text { border } \\
\text { with } \\
\text { Myanma } \\
r \text { and } \\
\text { China on } \\
\text { March } \\
30 . \\
\text { Other } \\
\text { parts are } \\
\text { closed }\end{array}$ & $\begin{array}{l}\text { All } \\
\text { traveling } \\
\text { in and out } \\
\text { of Laos } \\
\text { event } \\
\text { document } \\
\text { holders } \\
\text { are } \\
\text { prohibited } \\
\text { together } \\
\text { with the } \\
\text { suspendin }\end{array}$ & \multicolumn{2}{|c|}{$\begin{array}{l}\text { On March 19, } \\
\text { schools, bars, } \\
\text { entertainment } \\
\text { venues, and } \\
\text { major } \\
\text { shopping } \\
\text { centres were } \\
\text { ordered to shut } \\
\text { down. } \\
\text { Prohibition for } \\
\text { over } 10 \text { people } \\
\text { gatherings }\end{array}$} & \multicolumn{2}{|c|}{$\begin{array}{l}\text { National stay- } \\
\text { at-home order } \\
\text { including } \\
\text { closing } \\
\text { provincial } \\
\text { borders was } \\
\text { issued on } \\
\text { March } 30 \text {. } \\
\text { A 14-day self- } \\
\text { quarantine is } \\
\text { required for } \\
\text { citizen }\end{array}$} & $\begin{array}{l}\text { On March } \\
\text { 20, a } \\
\text { preliminar } \\
\text { y 13-part } \\
\text { stimulus } \\
\text { package } \\
\text { was } \\
\text { approved } \\
\text { during the } \\
\text { cabinet's } \\
\text { monthly } \\
\text { meeting. }\end{array}$ \\
\hline
\end{tabular}




\begin{tabular}{|c|c|c|c|c|c|c|c|}
\hline & & & $\begin{array}{l}\text { by the } \\
\text { neighbou } \\
\text { r nations } \\
\text { (Thailan } \\
\text { d and } \\
\text { Vietnam } \\
\text { ) }\end{array}$ & $\begin{array}{l}\mathrm{g} \text { of all } \\
\text { visa types }\end{array}$ & $\begin{array}{l}\text { Closed private } \\
\text { hospitals and } \\
\text { clinics } \\
\text { nationwide. }\end{array}$ & $\begin{array}{l}\text { returned back } \\
\text { from the } \\
\text { outside. }\end{array}$ & $\begin{array}{l}\text { LAK10 } \\
\text { billion } \\
\text { (USD 1.1 } \\
\text { million) }\end{array}$ \\
\hline $\begin{array}{l}\text { 5.Mala } \\
\text { ysia }\end{array}$ & $\begin{array}{l}\text { Moveme } \\
\text { nt } \\
\text { Control } \\
\text { Order } \\
16 \\
\text { March } \\
2020\end{array}$ & $\begin{array}{l}\text { The first } \\
\text { country to } \\
\text { report cases } \\
\text { because of } \\
\text { large } \\
\text { religious } \\
\text { gatherings. }\end{array}$ & $\begin{array}{l}\text { Seal off } \\
\text { borders } \\
\text { on } \\
\text { March } \\
16 \text { (the } \\
\text { first } \\
\text { country } \\
\text { shut its } \\
\text { borders } \\
\text { in the } \\
\text { region) }\end{array}$ & $\begin{array}{l}\text { Ban all } \\
\text { visitors } \\
\text { and bar } \\
\text { their } \\
\text { citizen to } \\
\text { travel } \\
\text { overseas } \\
\text { on March } \\
16\end{array}$ & $\begin{array}{l}\text { The restriction } \\
\text { is set for the } \\
\text { daily essentials } \\
\text { list of fewer } \\
\text { than } 10 \text { items } \\
\text { and within } 10 \\
\mathrm{~km} \text { from } \\
\text { citizens' } \\
\text { homes. }\end{array}$ & $\begin{array}{l}\text { Placed under } \\
\text { quarantine } \\
\text { beginning on } \\
\text { March 18. }\end{array}$ & $\begin{array}{l}\text { Three } \\
\text { economic } \\
\text { stimulus } \\
\text { packages } \\
\text { have been } \\
\text { revealed to } \\
\text { aid society. } \\
\text { RM270 } \\
\text { billion } \\
\text { (USD63 } \\
\text { billion) }\end{array}$ \\
\hline $\begin{array}{l}\text { 6.Myan } \\
\text { mar }\end{array}$ & $\begin{array}{l}\text { COVID- } \\
19 \\
\text { Control } \\
\text { and } \\
\text { Emergen } \\
\text { cy } \\
\text { Respons } \\
\text { es } \\
\text { Committ } \\
\text { ee } \\
31 \\
\text { March } \\
2020\end{array}$ & $\begin{array}{l}\text { Lack of } \\
\text { testing led } \\
\text { to delay of } \\
\text { reported } \\
\text { cases (the } \\
\text { first cases } \\
\text { was } \\
\text { detected on } \\
\text { March 23) }\end{array}$ & $\begin{array}{l}\text { Land } \\
\text { borders } \\
\text { with } \\
\text { China } \\
\text { are } \\
\text { closed } \\
\text { excludin } \\
\text { g goods } \\
\text { and } \\
\text { crew. } \\
\text { India has } \\
\text { closed its } \\
\text { border } \\
\text { with } \\
\text { Myanma } \\
\text { r. }\end{array}$ & $\begin{array}{l}\text { All } \\
\text { internation } \\
\text { al flights } \\
\text { and visas } \\
\text { (except to } \\
\text { diplomats) } \\
\text { are } \\
\text { suspended } \\
\text { from } \\
\text { March } 30 .\end{array}$ & $\begin{array}{l}\text { All economy } \\
\text { sectors which } \\
\text { did not } \\
\text { directly serve } \\
\text { for the fight of } \\
\text { the pandemic } \\
\text { have been } \\
\text { closed from } \\
\text { April } 7 . \\
\text { Bars are } \\
\text { closed and } \\
\text { malls are } \\
\text { opened for } \\
\text { limit periods. }\end{array}$ & $\begin{array}{l}\text { A lockdown } \\
\text { was set up for } \\
\text { Yangon only. } \\
\text { 14-day } \\
\text { quarantine is } \\
\text { compulsory } \\
\text { for workers } \\
\text { returning from } \\
\text { outside and } \\
\text { those with } \\
\text { "potentially } \\
\text { infected" }\end{array}$ & $\begin{array}{l}\text { A financial } \\
\text { aid was } \\
\text { established } \\
\text { for } \\
\text { affected } \\
\text { business } \\
\text { and health } \\
\text { sectors. } \\
100 \text { billion } \\
\text { Kyats (US } \\
\$ 70 \\
\text { million }\end{array}$ \\
\hline $\begin{array}{l}\text { 7.Philip } \\
\text { pines }\end{array}$ & $\begin{array}{l}\text { The } \\
\text { Bayanih } \\
\text { an to } \\
\text { Heal as } \\
\text { One Act } \\
23 \\
\text { March } \\
2020\end{array}$ & $\begin{array}{l}\text { Ranked the } \\
\text { first in } \\
\text { terms of the } \\
\text { incidence } \\
\text { cases daily. }\end{array}$ & $\begin{array}{l}\text { No } \\
\text { border } \\
\text { sharing }\end{array}$ & $\begin{array}{l}\text { All flights } \\
\text { have been } \\
\text { cancelled } \\
\text { until April } \\
14 . \\
\text { Foreigners } \\
\text { are } \\
\text { banned } \\
\text { from } \\
\text { entry, } \\
\text { excluding } \\
\text { Filipinos } \\
\text { citizens } \\
\text { and } \\
\text { special } \\
\text { officials. }\end{array}$ & $\begin{array}{l}\text { Worshipers } \\
\text { have asked to } \\
\text { stay at home } \\
\text { and follow } \\
\text { online } \\
\text { celebrations } \\
\text { during Holy } \\
\text { Week }\end{array}$ & $\begin{array}{l}\text { Close islands } \\
\text { step-by-step } \\
\text { starting from } \\
\text { the main } \\
\text { island of } \\
\text { Luzon } \\
\text { (including } \\
\text { Manila) on } \\
\text { March 16 }\end{array}$ & $\begin{array}{l}\text { Financial } \\
\text { supports } \\
\text { were } \\
\text { allocated } \\
\text { for local } \\
\text { authorities } \\
\text { and social } \\
\text { protection } \\
\text { program. } \\
\$ 3.9 \text { billion } \\
\text { social } \\
\text { protection }\end{array}$ \\
\hline $\begin{array}{l}\text { 8.Singa } \\
\text { pore }\end{array}$ & $\begin{array}{l}\text { (Tempor } \\
\text { ary } \\
\text { Measure } \\
\text { s) } \\
\text { COVID- } \\
19 \text { Act }\end{array}$ & $\begin{array}{l}\text { A global } \\
\text { leader in its } \\
\text { early and } \\
\text { aggressive } \\
\text { response } \\
\text { but }\end{array}$ & $\begin{array}{l}\text { Closed } \\
\text { by } \\
\text { Malaysia } \\
\text {. }\end{array}$ & $\begin{array}{l}\text { On } \\
\text { January } \\
31, \\
\text { prohibited } \\
\text { all China } \\
\text { visitors }\end{array}$ & $\begin{array}{l}\text { April 3, } \\
\text { schools and all } \\
\text { non-essential } \\
\text { businesses are } \\
\text { closed. }\end{array}$ & $\begin{array}{l}\text { All } \\
\text { dormitories of } \\
\text { more than } \\
20,000 \\
\text { migrant } \\
\text { workers were }\end{array}$ & $\begin{array}{l}\text { On April 6, } \\
\text { the third } \\
\text { round of } \\
\text { support } \\
\text { measures }\end{array}$ \\
\hline
\end{tabular}




\begin{tabular}{|c|c|c|c|c|c|c|c|}
\hline & $\begin{array}{l}7 \text { April } \\
2020\end{array}$ & $\begin{array}{l}\text { currently } \\
\text { experiencin } \\
\mathrm{g} \text { a second } \\
\text { wave of } \\
\text { cases from } \\
\text { pockets of } \\
\text { migrant } \\
\text { workers }\end{array}$ & & $\begin{array}{l}\text { and } \\
\text { expanded } \\
\text { to all } \\
\text { short-term } \\
\text { visitors on } \\
\text { March 22. }\end{array}$ & $\begin{array}{l}\text { Banned all } \\
\text { non- } \\
\text { household } \\
\text { members } \\
\text { gatherings of } \\
\text { any size. } \\
\text { April 9, parks } \\
\text { and sports } \\
\text { stadiums will } \\
\text { be closed if } \\
\text { people } \\
\text { continuously } \\
\text { gather } \\
\text { outdoors. }\end{array}$ & $\begin{array}{l}\text { put into } \\
\text { quarantine } \\
\text { from April } 5\end{array}$ & $\begin{array}{l}\text { was } \\
\text { announced }\end{array}$ \\
\hline $\begin{array}{l}\text { 9.Thail } \\
\text { and }\end{array}$ & $\begin{array}{l}\text { Emergen } \\
\text { cy } \\
\text { Decree } \\
26 \\
\text { March } \\
2020\end{array}$ & $\begin{array}{l}\text { Inconsistent } \\
\text { policies } \\
\text { over travel } \\
\text { and } \\
\text { quarantine, } \\
\text { poor } \\
\text { communicat } \\
\text { ion, and } \\
\text { supply } \\
\text { shortages }\end{array}$ & $\begin{array}{l}\text { All } \\
\text { borders } \\
\text { were } \\
\text { closed } \\
\text { on } \\
\text { March } \\
22 .\end{array}$ & $\begin{array}{l}\text { Foreign } \\
\text { visitors } \\
\text { are } \\
\text { banned } \\
\text { starting on } \\
\text { March } 22 .\end{array}$ & $\begin{array}{l}\text { Alcohol sale } \\
\text { points were } \\
\text { prohibited } \\
\text { from April } 10 . \\
\text { Schools } \\
\text { remain closed } \\
\text { till July } 1 .\end{array}$ & $\begin{array}{l}\text { A national } \\
\text { curfew was set } \\
\text { from } 10 \text { p.m. } \\
\text { to } 4 \text { a.m. } \\
\text { starting April } \\
3\end{array}$ & $\begin{array}{l}\text { On April 7, } \\
\text { the third } \\
\text { stimulus } \\
\text { measure } \\
\text { was issued } \\
\text { by the } \\
\text { cabinet. } \\
\text { Lending } \\
\text { rates will } \\
\text { be cut. } \\
100 \text { billion } \\
\text { baht } \\
\text { (USD3.2 } \\
\text { billion) } \\
117 \text { billion } \\
\text { baht } \\
\text { (US } \$ 3.56 \\
\text { billion }\end{array}$ \\
\hline $\begin{array}{l}\text { 10. Viet } \\
\text { nam }\end{array}$ & $\begin{array}{l}\text { National } \\
\text { Steering } \\
\text { Committ } \\
\text { ee for } \\
\text { COVID- } \\
19 \\
\text { Preventi } \\
\text { on and } \\
\text { Control } \\
31 \\
\text { January } \\
2020\end{array}$ & $\begin{array}{l}\text { The } \\
\text { pandemic } \\
\text { managemen } \\
\mathrm{t} \text { is } \\
\text { relatively } \\
\text { well even } \\
\text { with limited } \\
\text { resources } \\
\text { and sharing } \\
\text { bustling } \\
\text { borders } \\
\text { with China. }\end{array}$ & $\begin{array}{l}\text { Border } \\
\text { sharing } \\
\text { with } \\
\text { Cambodi } \\
\text { a and } \\
\text { Laos was } \\
\text { closed } \\
\text { from } \\
\text { March } \\
31 .\end{array}$ & $\begin{array}{l}\text { Banned all } \\
\text { flights to } \\
\text { and from } \\
\text { China } \\
\text { from } \\
\text { February } \\
1 .\end{array}$ & $\begin{array}{l}\text { Banning on } \\
\text { public } \\
\text { gatherings of } \\
\text { over } 20 \text { people } \\
\text { and } \\
\text { suspending } \\
\text { non-essential } \\
\text { public services } \\
\text { from April } 1 .\end{array}$ & $\begin{array}{l}\text { The } \\
\text { quarantine } \\
\text { was } \\
\text { completely } \\
\text { placed in } \\
\text { several high- } \\
\text { risk areas from } \\
\text { mid- February. } \\
\text { A } 15 \text {-day } \\
\text { national } \\
\text { lockdown } \\
\text { began April } 1 .\end{array}$ & $\begin{array}{l}\text { The fiscal } \\
\text { package } \\
\text { was } \\
\text { focused on } \\
\text { the most } \\
\text { affected by } \\
\text { the } \\
\text { pandemic } \\
\text { in early } \\
\text { April }\end{array}$ \\
\hline
\end{tabular}

Table 5: Nine of the indicators of government policies recorded on ordinal scale (Source: Oxford COVID-19 Government Response Tracker, www.covidtracker.bsg.ox.ac.uk)

\begin{tabular}{|c|c|c|c|c|c|c|c|c|c|}
\hline \multirow[t]{2}{*}{ Countries } & \multicolumn{9}{|c|}{ Indicators* } \\
\hline & $\begin{array}{l}\text { Clo } \\
\text { sur } \\
\text { e } \\
\text { of } \\
\text { Sc } \\
\text { ho } \\
\text { ol a }\end{array}$ & $\begin{array}{l}\text { Closure } \\
\text { of } \\
\text { Workpl } \\
\text { ace b }\end{array}$ & $\begin{array}{l}\text { Cancellat } \\
\text { ion of } \\
\text { public } \\
\text { eventsc }\end{array}$ & $\begin{array}{l}\text { Restricti } \\
\text { ons on } \\
\text { gatherin } \\
\text { gSd }\end{array}$ & $\begin{array}{l}\text { Closur } \\
\text { e of } \\
\text { Public } \\
\text { transp } \\
\text { ort e }\end{array}$ & $\begin{array}{l}\text { Sta } \\
\text { y at } \\
\text { ho } \\
\text { me f }\end{array}$ & $\begin{array}{l}\text { Restricti } \\
\text { ons on } \\
\text { internal } \\
\text { moveme } \\
\text { nte }\end{array}$ & $\begin{array}{l}\text { Internatio } \\
\text { nal travel } \\
\text { controlg }\end{array}$ & $\begin{array}{l}\text { Public } \\
\text { info } \\
\text { campai } \\
\text { gnh }\end{array}$ \\
\hline
\end{tabular}




\begin{tabular}{|l|c|c|c|c|c|c|c|c|c|}
\hline $\begin{array}{l}\text { Brunei } \\
\text { Darussalam }\end{array}$ & 3B & 3B & 2B & 3B & 2B & 0 & 0 & 4 & $2 \mathrm{~B}$ \\
\hline Cambodia & NA & NA & NA & NA & NA & NA & NA & NA & NA \\
\hline Indonesia & 2A & 2A & 2A & 4A & 2A & 1B & 2B & 4 & 2B \\
\hline Lao PDR & 3B & 3B & 2B & 4B & 2B & 2B & 2B & 4 & 2B \\
\hline Malaysia & 3B & 3B & 2B & 2B & 0 & 0 & $2 \mathrm{~B}$ & 3 & 2B \\
\hline Myanmar & 3B & 3A & 2B & 4B & 2A & 2A & 2A & 3 & 2B \\
\hline Philippines & 3B & 1B & 2B & 3B & 2B & 2B & 2B & 2 & 1B \\
\hline Singapore & 3B & 3B & 2B & 4B & 1B & 1A & 1B & 2 & $2 \mathrm{~B}$ \\
\hline Thailand & 3B & 3A & 2A & 3A & 2A & 1B & 2A & 4 & 2B \\
\hline Vietnam & 3A & 2B & 2B & 3B & 2B & 0 & 2A & 4 & 2B \\
\hline
\end{tabular}

* Updated to 24/04/2020

A: apply only in a geographically concentrated area,

B: apply throughout the entire jurisdiction

a 0 - No measures; 1 - Recommend closing; 2 - Require closing (only some levels or categories); 3 - Require closing all levels

b 0 - No measures; 1 - Recommend closing; 2 - Require closing (only some sectors or categories of workers); 3 -

Require closing all-but-essential workplaces (eg grocery stores, doctors)

c 0- No measures; 1 - Recommend cancelling; 2 - Require cancelling

d 0- No restrictions; 1 - Restrictions on very large gatherings (the limit is about 1000 people); 2 - Restrictions on gatherings between 100-1000 people); 3 - Restrictions on gatherings between 10-100 people); 4 - Restrictions on gatherings of less than 10 people

e 0 - No measures; 1 - Recommend closing (or significantly reduce volume/route/means of transport available); 2 -

Require closing (or prohibit most citizens from using it)

f 0 - No measures; 1 - Recommend not leaving house; 2 - Require not leaving house with exceptions for daily

exercise, grocery shopping, and "essential” trips; 3 - Require not leaving house with minimal exceptions

g 0 - No measures; 1 - Screening; 2 - Quarantine on high-risk regions; 3 - Ban on high-risk regions

h 0 -No COVID-19 public information campaign; 1 - Public officials urging caution about COVID-19; 2 -

Coordinated public information campaign (e.g. across traditional and social media)

NA: Not available 


\section{Comparing the ASEAN and member countries' responses: a policy science analysis}

A recent paper asks a question on how policy sciences help us understand the responses to COVID-19 pandemic (Weible et al. 2020). Weible et al wrote that the policy science framework was proposed by Lasswell (1956) to examine situations, challenging and informing ongoing processes and decisions, and foretelling of future scenarios, by which these actions are intended to steer government and society toward the common goal of dignified society for all (Weible et al. 2020). They propose 10 viewpoints to examine the responses: on policy making (within the country), crisis response and management, global policymaking and transnational administration, policy networks, implementation and administration, scientific and technical expertise, emotions, narratives and messaging, learning, and policy success and failure (Table 6). We further group these issues into 3 major ones of a) policy and decision making, b) communication and perception, c) science and learning, and utilise it as a framework for analysis to compare ASEAN and the member states' responses.

Table 6: Policy sciences (Sources: Modified from Weible et al (2020) based on Lasswell (1956)

\begin{tabular}{|l|l|}
\hline $\begin{array}{l}\text { Policy Sciences } \\
\text { perspectives }\end{array}$ & Issues to consider \\
\hline Policy and decision making \\
\hline $\begin{array}{l}\text { 1. Policy making } \\
\text { within country) }\end{array}$ & $\begin{array}{l}\text { Policy making (within the country) } \\
\text { Uncertainties exist regarding the duration and termination of policy decisions } \\
\text { Government non-decisions become just as important as decisions }\end{array}$ \\
\hline $\begin{array}{l}\text { 2. Crisis response and } \\
\text { management }\end{array}$ & $\begin{array}{l}\text { Responses occur at strategic and operational levels } \\
\text { Mitigating value conflicts spark public controversies and blame-games } \\
\text { Transboundary crises can both spur and challenge collaboration }\end{array}$ \\
\hline $\begin{array}{l}\text { 3. Global } \\
\text { policymaking and } \\
\text { transnational } \\
\text { administration }\end{array}$ & $\begin{array}{l}\text { Inequalities drive differential impacts of policy responses, which, in turn, exacerbate } \\
\text { inequalities } \\
\text { Destabilization and reinforcement of global policy processes } \\
\text { Uncertainty about the locus of authority and influence of global professionals }\end{array}$ \\
\hline $\begin{array}{l}\text { 4. Policy networks } \\
\text { Policy networks react and contribute to the shifting of attention to policy issues and } \\
\text { changing of government agendas } \\
\text { Prior policy networks condition policy and societal responses } \\
\text { Changes in importance of policy networks' people and organizations, relations, and } \\
\text { resources }\end{array}$ \\
\hline $\begin{array}{l}\text { 5. Implementation } \\
\text { and administration }\end{array}$ & $\begin{array}{l}\text { Administrative fragmentation and decentralization complicate implementation } \\
\text { Front-line workers exercise discretion and self-regulation } \\
\text { Co-production requires overcoming collective action challenges }\end{array}$ \\
\hline $\begin{array}{l}\text { Communication and perception } \\
\text { povernments appeal to emotions to help legitimize policy responses and steer public } \\
\text { Emotionally charged language can recall cultural and historical contexts } \\
\text { Policy responses force a reevaluation of the emotional spheres in societies }\end{array}$ \\
\hline
\end{tabular}




\begin{tabular}{|l|l|}
\hline $\begin{array}{l}\text { 7. Narratives and } \\
\text { messaging }\end{array}$ & $\begin{array}{l}\text { Governments attempt to provide sufficient information in a timely manner to the public } \\
\text { Governments attempt to provide information that is accurate and non-contradictory to the } \\
\text { public } \\
\text { Governments can spawn controversies by engaging in speculations }\end{array}$ \\
\hline Science and learning & \\
\hline $\begin{array}{l}\text { 8. Scientific and } \\
\text { technical expertise }\end{array}$ & $\begin{array}{l}\text { Scientific and technical experts become more central in policy responses to uncertain } \\
\text { problems } \\
\text { Governments invoke scientific and technical expertise to inform and legitimize problems, } \\
\text { responses, and evaluations } \\
\text { Scientific and technical expertise can obscure accountability of decisions }\end{array}$ \\
\hline 9. Learning & $\begin{array}{l}\text { Urgency triggers learning from others' experiences } \\
\text { Learning manifests in different ways } \\
\text { Different barriers inhibit learning }\end{array}$ \\
\hline $\begin{array}{l}\text { 10. Policy success } \\
\text { and failure }\end{array}$ & $\begin{array}{l}\text { Who is affected and to what extent influence frames of success or failure } \\
\text { Success or failure judged as part of decisions, processes, and politics } \\
\text { It is possible to conceive of a spectrum from success to failure } \\
\text { Lenses and narratives shape perceptions of success and failure }\end{array}$ \\
\hline
\end{tabular}

\subsection{Policy and decision making}

\subsubsection{Policy perspectives}

Governments adopt public policies through different pathways: (1) Learning: COVID-19 is a novel virus. There is knowledge uncertainty around it. One key reference is WHO's information on COVID-19 and policy reference is benchmarked around what other countries have been doing including neighbours. WHO's advice to track and trace every case has been implemented by ASEAN member states such as Singapore and Malaysia. Thailand and the Philippines have confirmed dozens of cases in January 2020. The other ASEAN members such as Indonesia were late in confirming cases, only in March 2020. In addition, countries in ASEAN also learn from other successful countries in dealing with this pandemic such as mitigating the impacts with partial closure for example in Malaysia, Singapore, Indonesia and started to shift their policy to more stricter such as lockdown or more large scale quarantine following the surge of infection in their countries. (2) Negotiated agreement is demonstrated by passing stimulus packages in every ASEAN country and agreement in Regional ASEAN to establish COVID 19 Response Fund in April 2020, and (3) Diffusing and transferring ideas across governments is shown that every country has their own characteristic and their own value and culture.

\subsubsection{Crisis response and management}

There are similarities and differences in crisis response and management in every southeast ASEAN country to COVID-19. In Indonesia for example strategic responses are coming from the President while in some other countries are in hand of Prime Ministers such as in Malaysia and Singapore. While, operational levels in every country differ for example some countries like Indonesia and Lao PDR have established task forces while other countries do not, and some countries mobilize army and policy to enforce the compliance of society for quarantine some not. Some countries have volunteered for medical responses some not. Brunei, Singapore and Vietnam have 
been praised to have a successful response. Although, Singapore has a second wave of infection mostly at foreignworkers accommodations. Despite successful stories, public controversies and blame games have occurred in dealing with pandemic in many countries including ASEAN particularly on the issue of measures between saving life and saving the economy which is conflicting with each other. Criticism occurred whether the government was doing good enough, timely enough to contain the virus. Conflict between different levels of government in dealing with such problems creates trouble for many world leaders, such as in Indonesia, Cambodia and Myanmar. Indeed, communication failures, political values and identities, and weak mandates can undermine efforts to achieve a collective crisis response (Boin 2016).

\subsubsection{Global policymaking and transnational administration}

There is a growing inequality in ASEAN as an impact to COVID-19. Poverty is one reason some ASEAN countries could not implement strict lockdown such as in Indonesia and Philippines. In addition, vulnerable groups such as migrant workers continue to benefit less from development in ASEAN. It showed that they are proven vulnerable to get more infections than any other groups or society for example the cases of infection in Singapore surged in migrant workers clusters. While in ASEAN the response puts more emphasis on extensive measures of member states in the first place. Regional cooperation is emerging in later stages with exchange information and information sharing among member states and ASEAN Respond Fund COVID-19 to assist member states that need funding. It is disrupting tourism and travel, supply chains and labour supply. Among ASEAN countries, Singapore, Malaysia and Thailand are heavily integrated in regional supply chains and will be the most affected by a reduction in demand for the goods produced within them. Indonesia and the Philippines have been increasing supply chain engagement and will also not be immune. Vietnam is the only new ASEAN member integrated into supply chains with China and is already suffering severe supply disruptions.

\subsubsection{Policy networks}

ASEAN policy approach to past epidemics has been grounded on its unique and pragmatic networks in what is socalled as the ASEAN Plus Three (APT) (including China, Japan and South Korea) for regional disease surveillance mechanisms has developed a Protocol for Communication and Information Sharing on Emerging Infectious Diseases, with a standardized Protocol for Communication and Information Sharing on Emerging Infectious Diseases that encourages member states to report all cases of diseases that are categorized as a Public Health Emergency of International Concern (PHEIC)[3]. For example, Past programmes include the cooperation of Disaster Safety of Health Facilities and the ASEAN + 3 Field Epidemiology Training Network as well as the ASEAN Regional Public Health Laboratories Network (RPHL) through the Global Health Security Agenda platform. However, it is not clear how such networks contribute to effective policy making during the storm of COVID-19.

\subsubsection{Implementation and administration}

Response of COVID-19 needs inter-agency collaboration across fragmented and sectoral bureaucracy. Some of ASEAN countries had difficulties to have interagency collaboration due to sectoral ego. Hierarchical coordination, power struggle between levels of government such as in Indonesia decentralization complicate the effective response. The pandemic has disrupted the daily lives routine in all ten ASEAN countries. In slowing down the 
spread of COVID-19 behaviour changes are needed. People were forced to stay at home for months or more to prevent the further spread of the virus. Work, study and even prayer activities have been affected and should do these activities at home instead and conducted online. The effort of social distancing has been applied to all ten Member countries. Malaysia for example has implemented a Movement Control Order (MCO) since 18 March 2020. This MCO has extended to April 28, 2020. Similarly, in Indonesia Indonesian President Jokowi appeals to citizens to work, study and pray at home on 15 of March 2020. This social distancing has been continued with the order of large-scale social restriction in major cities in Indonesia in Jakarta for example adopted until 23 April 2020 and this has been extended. In Singapore, closure of the workplace has to be implemented for 28 days "circuit breakers" from April 3, 2020. The Philippines also implemented community quarantine in metro Manila on 13 of March 2020 and in other parts of its region. The community needs to comply with strict measures. Social distancing was also adopted in 12 cities in Vietnam.

\subsection{Communication and perception}

\subsubsection{Emotions and public policy}

Succeed in changing behaviour during COVID-19 include establishing trust in health authorities, recommendation and information. Citizen willingness to cooperate to social distancing and understanding the threat with maintaining good hygiene and immune systems have been the key to cope with pandemic. However, for many social distancing is not an option. For example, in Philippine as they struggle to meet daily needs, they fear death from hunger and anxiety rather than from infection. Similarly, with Indonesia when fulfilling the daily needs are more important than staying at home. In addition, wearing a mask in some countries has become mandatory as recently in Indonesia Jokowi appealed to citizens to wear masks in the public. Fear of the virus spread also created some unacceptable discriminatory behaviours such as in Cambodia where member of the public posted hateful Facebook comments in reaction to the Health Ministry's original statement, blaming Cambodia's Muslim communities of or the spread of the virus in the country. Similarly in Indonesia, people in some local region has rejected the death because of victims were going to be buried in their areas because of infection fear. They need more education and awareness of the community on the threat, to massively campaign particularly what should do and not do at local community level.

\subsubsection{Narratives and messaging}

Governments that communicate and provide sufficient information and transparent manner could win the public trust during the pandemic. However, at the beginning of announcing the first confirmed cases of COVID-19 in their countries, the public tends to react by conducting mass panic buying. Panic buying at the beginning of the pandemic occurred in several ASEAN countries including Malaysia, Singapore, Indonesia. Greater trust of the government led to much greater compliance of government advisory to wear masks in public for example. Singapore's Prime Minister Lee Hsien Loong and Vietnam's Deputy Prime Minister Vu Duc Dam have been models of effective communication and transparency (Zachary Abuza April 21, 2020). 


\subsection{Science and learning}

\subsubsection{Scientific and technical experts and information}

Scientific, medical and public health experts are evidently central in policy responses to COVID-19. Indonesia proposed the establishment of ASEAN-China Ad-Hoc Health Ministers Joint Task Force during the Special Meeting of the Ministers of Foreign Affairs of ASEAN and People's Republic of China (PRC) on February 20, 2020. The Task Force is expected to focus on the exchange of information and data, especially in handling the outbreak, organizing expert team meetings, and encouraging joint research and production for virus detection and vaccine (Ministry of Foreign Affairs of the Republic of Indonesia 20 February 2020). More recently, during the ASEAN Plus Three (APT) Summit, April 14, 2020, the Indonesian President called for leaders to provide guidance to the Health Ministers to strengthen research collaboration to create anti viruses and vaccines. In anticipation of a pandemic going forward, Indonesia also proposed the establishment of an APT country special task force for a pandemic whose task would be to provide comprehensive steps to strengthen the resilience of the APT Region in the face of a future pandemic (Embassy of the Republic of Indonesia 14 Apr 2020). The pandemic however actually has exposed disparity in terms of capacity, role and influence of communities of scientific and technical experts across ASEAN countries. Across the region, governments who made decisions based on medical and scientific evidence — relying on public health and medical officials - have come out on top. Governments who have made their decisions based on short-term economic and political calculations have not been able to get ahead of the situation (Zachary Abuza April 21, 2020). In ASEAN countries where the pandemic responses have been more effective, scientific, medical and public health experts have played important roles in decision-making processes.

\subsubsection{Learning}

Lessons learned from their own nations and other neighbours when dealing with the previous epidemic could provide valuable insight into the combat with this current pandemic. In parallel with SARS and MERS, COVID-19 was found to share a similar characteristic of origin, symptoms and host immune response (Prompetchara et al.). Thus, it creates a change to boost the national responses to combat the infection and prepares for an outbreak of similar coronavirus in the future. Several triggers need to be urgently improved including surge healthcare capacity, infection prevention and control and update information for the whole public. To improve healthcare capacities, various supports were allocated from their own national budget or even sent from international organizations and nearby nations. Singapore, Indonesia, Myanmar, and Philippines activated their economic stimulus package for healthcare spending. Besides, the World Bank, Asian Development Bank also supported Cambodia, Indonesia, Laos to the purchase of medical supplies. Whereas, Singapore, Vietnam and other nations (China, South Korea, Japan, USA) also aid their neighbouring ASEAN countries by training medical workers, medical supplies or even sending medical experts. Furthermore, public information campaign existed in all nations as assessed from the Oxford COVID-19 Government Response Tracker (Oxford COVID-19 Government Response Tracker 2020). This brings the benefits of the digital evolution to broaden and daily update information for the whole population. 


\subsubsection{Policy success and failure}

During COVID-19 onset during January - February 2020, ASEAN's “One ASEAN - One Response” (OAOR) framework was put to the test. Despite OAOR's main focus on natural hazards, however, some of the ASEAN disaster committee members have been the leading agencies responding to COVID-19 such as in Indonesia. In addition, despite being proven relatively successful in the past, the ASEAN coordinated response seems less visible in the first quarter of 2020. The impact on ASEAN economy will be tremendous. Unfortunately, ASEAN did not discuss quite meaningfully to protect its interest in the integrity of ASEAN Economic Communities including its Blueprint 2025 that would offer US\$2.6 trillion for over 622 million people (that have been implemented in 2016 (Association of Southeast Asean Nations (ASEAN) 2020b).

The "One Vision, One Identity, One Community" seems to be a utopia as each ASEAN member state treats their borders as their absolute sovereignty while lacks the vision of "greater good" for all. Therefore, fuller understanding ASEAN's response to COVID-19 should be based on individual analysis of each member. Most ASEAN countries have implemented measures to contain the virus by closing borders, travel restrictions, closure of schools, working place, lockdown or quarantine. The existing principle of non-interference and the reliance on action of individual member states in the first place and lack of clarity on the scale of the impact may explain the lack of early and collective action, at the end of January or early February, from regional ASEAN to address the pandemic. The meeting on 20 February of ASEAN-China foreign ministers meeting in Vientiane, Laos was a watershed in bringing together China and ASEAN member states to combat the pandemic.

\section{Toward broader ASEAN health system resilience}

This paper has documented and analysed ASEAN as a regional organisation and the 10 member states respond to COVID-19. Our main finding is that regional responses in the beginning of the pandemic (January and February 202)0 were considerably slow and lack of unity. Extensive early measures laid with the member states, which were critical to curb the spread of the virus. In March and April 2020, ASEAN has actively reconvened and utilised its existing health regional mechanism to try to have a coherent response to the impacts. There is more action that needs to be done to curb the virus in the region. Strengthening future collaboration should be implemented by recognizing that there is a more coherent, multi sectoral, multi stakeholders and whole-of-ASEAN Community approach in ensuring ASEAN's timely and effective response to the pandemic.

COVID-19 shows that shocks and changes can occur anytime and at different scales, and health systems need to have the ability to absorb, adapt and transform in dealing with the shocks. This concept is called health systems resilience (Kutzin 2016). Resilience is critical for health systems to be able to avoid disruption, collapse or even total failure. Health systems need to have the following six functions to be able to deliver safe, quality and sound health services: leadership and governance, information, health workforce, medical products, service delivery and financing (Fridell et al. 2020). We have discussed in detail in Section 4 how leadership and time and tactful national governance is the key factor for successful COVID-19 early response. The provision of accurate, timely, and relevant information which is delivered in a clear and authoritative manner helps to build trust from the public to government and in turn encourage compliance to behavioural changes needed and adherence to the movement restriction. The next three functions are related to the health systems capacity of the health workforce, medical 
products and service delivery. Flattening the curve is about early and decisive actions to delay the impacts reaching the peak and lowering the peak as well so that the health system will have more time to prepare and get on top of the impacts. The last issue is about financing, which is related to short-term and urgent needs for testing, tracing, and treatment and also larger, longer term financial stimulus to deal with the impacts as well as investment in health system to be better prepared for pandemic, or any other large-scale health emergencies.

Finally, we are entering the super year of sustainability through accelerated implementation of the Sustainable Development Goals (SDGs), along with other global frameworks such as the Paris Agreement on Climate change, the Sendai Framework for Disaster risk Reduction and the New Urban Agenda. Health is the cross-cutting issue within the global frameworks. ASEAN and its whole communities need to build health system resilience that is also just, green, and sustainable.

\section{References}

Anderson, R. M., Heesterbeek, H., Klinkenberg, D., \& Hollingsworth, T. D. (2020). How will country-based mitigation measures influence the course of the COVID-19 epidemic? The Lancet, 395(10228), 931-934, doi:10.1016/S0140-6736(20)30567-5.

Fears of coronavirus catastrophe as Myanmar reports first death. (1 Apr 2020, Aljazeera.

Coronavirus Spread from Malaysia event to multiple countries, 19 March 2020. (19 March 2020.

Coronavirus COVID-19 death rate in Indonesia is the highest in the world. Experts say it's because reported case numbers are too low. (23 MarMarch 2020.

Brunei's Response To COVID-19. (18 April 2020, The Asian Post.

Assian Development Bank (2020). The Economic Impact of the COVID-19 Outbreak on Developing Asia.

Thailand Imposes New Coronavirus Curfew. (April 02, 2020, The Diplomat.

Association of Southeast Asean Nations (ASEAN) (2018). ASEAN Post-2015 Health Development Agenda 20162020. In T. A. Secrectariat (Ed.). Jakarta.

Association of Southeast Asean Nations (ASEAN) (2020a). About ASEAN. https://asean.org/asean/aboutasean/overview/. Accessed April 292020.

Association of Southeast Asean Nations (ASEAN) (2020b). ASEAN Economic Community. https://asean.org/aseaneconomic-communityl. Accessed April 272020.

Association of Southeast Asean Nations (ASEAN) (2020c). ASEAN Health Sector Efforts in the Prevention, Detection and Response to Coronavirus Disease 2019 (COVID-19). https://asean.org/?static_post=updatesasean-health-sector-efforts-combat-novel-coronavirus-covid-19. Accessed April 292020.

Low testing means low COVID-19 cases? (31 March 2020, The Asean Post.

Thailand Issues Second COVID-19 Stimulus Package. (April 16, 2020, Asean Briefing.

Myanmar confirms first coronavirus cases. (24 Mar 2020, Bangkok Post.

The politics of crisis management: Public leadership under pressure. (2016, Cambridge University Press.

Republic Act 11469 or the Bayanihan to Heal as One Act. (March 25, 2020, The Manila Time.

Department of Budget and Management (2020). DBM releases P30.8B for Bayanihan Grant to cities, municipalities to address COVID-19. Philippines Information Agency. 
Department of Statistics Singapore (2020). Population. https://www.singstat.gov.sg/modules/infographics/population. Accessed April 272020.

Djalante, R., Shaw, R., \& DeWit, A. (2020). Building resilience against biological hazards and pandemics: COVID19 and its implications for the Sendai Framework. Progress in Disaster Science, 6, 100080, doi:https://doi.org/10.1016/j.pdisas.2020.100080.

Coronavirus in Malaysia: COVID-19 outbreak, measures and impact. (1 April 2020.

Yangon to impose lockdown measures for seven townships. (18 Apr 2020, Myanmar Time.

President Jokowi Encourages ASEAN+3 to Create Resilience Against Pandemic Covid-19 and Resilience for Economic Strengthening. (14 Apr 2020.

DOF to implement wage subsidy program for 3.4-M workers of small businesses. (14 Apr 2020.

Fridell, M., Edwin, S., von Schreeb, J., \& Saulnier, D. D. (2020). Health System Resilience: What Are We Talking About? A Scoping Review Mapping Characteristics and Keywords. International Journal of Health Policy and Management, 9(1), 6-16, doi:10.15171/ijhpm.2019.71.

Gianna Gayle Herrera Amul and Tikki Pang (2018). Regional Health Security: An Overview of Strengthening ASEAN's Capacities for the International Health Regulations. Global Health Governance, XII(No 2 (Fall 2018)).

Gong, L. (2020). COVID-19: Is the Humanitarian Sector Prepared. Global Health Security, No. 036.

Coronavirus: An unprecedented Singapore border closure, in unprecedented times. . (24 March 2020, The Straits Times.

"Thailand's Covid-19 death rate is a quarter of the world average, recovery rate is high". (19 Apr 2020, The Thaiger. Why Singapore, Once a Model for Coronavirus Response, Lost Control of Its Outbreak. (20 Apr 2020, Time.

International Science Council (2020). Indonesia COVID-19 Policy-Making Tracker. https://www.ingsa.org/covid/policymaking-tracker/asia/indonesial. Accessed April 292020.

Singapore's migrant workers are suffering the brunt of the country's coronavirus outbreak. (April 25, 2020, CNN.

KPMG (15 April, 2020). Economic stimulus measures. https://home.kpmg/xx/en/home/insights/2020/04/cambodiagovernment-and-institution-measures-in-response-to-covid.html.

Kutzin, J. a. S., S.P., (2016). Health systems strengthening, universal health coverage, health security and resilience. Bulletin of the World Health Organization, 94(1), p.2.

Covid-19 circuit breaker to be extended by one month to June 1: PM Lee. (22 Apr 2020, The Straits Times.

Minh Duc, N., Hoang Duc Ha, Tran Anh Tuan, Mai Tan Lien Bang, Pham Hong Duc, and Pham Minh Thong, (2020). From First COVID-19 Case to Current Outbreak: A Vietnamese Report. Electronic Journal of General Medicine, 17(4), em208.

Minister of Foreign Affairs Retno invites ASEAN and PRC to Strengthen Regional Mechanism to Cope with COVID19 Outbreak. (20 February 2020.

Myanmar Unveils \$70-Million Stimulus Package to Ease Economic Blow From Virus. (19 March 2020.

Devout at a distance in contagion-hit Brunei. (April 2, 2020, Asia Time. 
Oxford COVID-19 Government Response Tracker (2020). https://www.bsg.ox.ac.uk/research/researchprojects/oxford-covid-19-government-response-tracker. Accessed April 272020.

Coronavirus in Thailand: dealing with the 2019-nCoV (COVID-19) outbreak and impact

(31 Mar 2020.

Prompetchara, E., Ketloy, C., \& Palaga, T. Immune responses in COVID-19 and potential vaccines: Lessons learned from SARS and MERS epidemic. (0125-877X (Print)).

Fears as Cambodia grants PM vast powers under Covid-19 pretext. (10 Apr 2020, The guardian.

Laos Imposes Sweeping COVID-19 Lockdown Measures. (March 30, 2020, Tilleke \& Gibbins.

Cambodian PM urges people to remain vigilant despite no new Covid-19 cases for 12 straight days. (25 Apr 2020, The Star.

Suttinee Yuvejwattana, R. T.-K., and Anuchit Nguyen (7 Apr 2020). Thailand Plans \$30.5 Billion Borrowing for Latest Stimulus. https://www.bloomberg.com/news/articles/2020-04-07/thailand-plans-30-5-billion-in-newborrowing-for-major-stimulus. Accessed Apr 272020.

Cambodia confirms first local case of Covid-19. (07 Mar 2020, The Star.

Laos reports zero increase in Covid-19 cases. (17 Apr 2020, The Star.

Malaysia's nationwide Covid-19 response lauded. (24 Mar 2020, The Star.

VDB Loi (April 3, 2020). The Lao PDR government announces new economic policy measures. Accessed April 27 2020.

Vietnam Government (2020). Directive 16 / CT-TTG of the Prime Minister on the implementation of nationwide quarantine from April 1 to April 15

Vietnam Government news (03 Apr 2020). Latest update on Gov't responses to COVID-19 epidemic.

No community transmission cases reported over last 10 days. (26 Apr 2020.

Vietnam Ministry of Health (2020). Information on COVID-19 outbreak. https://ncov.moh.gov.vn/. Accessed April 272020.

Weible, C. M., Nohrstedt, D., Cairney, P., Carter, D. P., Crow, D. A., Durnová, A. P., et al. (2020). COVID-19 and the policy sciences: initial reactions and perspectives. Policy Sciences, doi:10.1007/s11077-020-09381-4.

Worldometers (2020). Cambodia. https://www.worldometers.info/coronavirus/country/cambodia/. Accessed April 28 2020.

Explaining Successful (and Unsuccessful) COVID-19 Responses in Southeast Asia. (April 21, 2020, The Diplomat.

Singapore confirms first case of Wuhan virus. (23 Jan 2020, Channel News Asia. 